\title{
Canadian and Cameroonian English-Speaking University Students' Compliment Strategies
}

\author{
Bernard Mulo Farenkia \\ Department of Languages and Letters, Cape Breton University \\ P) Box 5300, Sydney, Nova Scotia B1P6L2, Canada \\ Tel: 1-902-563-1870_E-mail: bernard_farenkia@cbu.ca
}

Received: April 10, 2013 Accepted: May 8, $2013 \quad$ Published: June 25, 2013

doi:10.5296/ijl.v5i3.3900ＵRL: http://dx.doi.org/10.5296/ijl.v5i3.3900

\begin{abstract}
This paper addressees compliment strategies in two regional varieties of English, namely Cameroon English and Canadian English. Data were collected through written Discourse Completion Tasks with 25 Canadian and 25 Cameroonian University students. The study examines similarities and differences between the two groups with regards to move structure and the head act strategies, the use of lexical and syntactic / stylistic devices and the use of supportive moves in six different situations. It was found that the Cameroonians show a very strong preference for single heads whereas the Canadians mostly favor multiple heads and that the Cameroonians use indirect compliments much more than the Canadians. The results reveal that the Canadians employ more lexical elements (adjectives, adverbs, verbs) than the Cameroonians. With regard to external modification of the core compliments, the findings suggest that the Canadians use much more supportive moves, i.e. pre-compliments and post-compliments, than the Cameroonians. Some differences were also found with regard to the situational distribution and types of internal and external modification devices.
\end{abstract}

Keywords: Compliment, Politeness, Regional variation, Cameroon English, Canadian English 


\section{Introduction}

There are numerous studies on the realization patterns and functions of compliments in English (Holmes 1986, Manes \& Wolfson 1981), Chinese (Ye, 1995; Yu, 2005), German (Golato, 2005) French (Kerbrat-Oreechioni, 1998; Traverso, 1996; Mulo Farenkia, 2009), and many other languages. To the best of my knowledge, there is no study on compliments in Canadian English. Also, there is a growing body of research on the performance of speech acts in different regional varieties of the same languages and such studies are undertaken within the framework of variational pragmatics (Schneider \& Barron, 2008). With regard to the types of speech acts examined, much research has focused on requests, apologies, thanks, invitations, etc. in pluricentric languages such as English, German, Spanish, French etc. ${ }^{1}$ As far as the speech act of complimenting is concerned, the very few studies available dwell on compliment strategies in Cameroon French and Canadian French (Mulo Farenkia 2012a, 2012 b, 2012c). The recent years have witnessed a rapid growth in the number of studies in variational pragmatics ${ }^{2}$ dealing with the realization of speech acts such as offers (Barron, 2005), responses to thanks (Schneider, 2005), requests (Barron, 2008), expressions of gratitude (Jautz, 2008), etc. in two or more varieties of English. Nevertheless, a great deal of work still remains to be done on speech act performance in Canadian English and Cameroon English. Also, compliments have been widely investigated in several regional varieties of English. However, there seems to be very little or no information on how English-speaking Canadians and Cameroonians express admiration. The present study attempts to provide such an analysis, by comparing the ways English-speaking Cameroonian and Canadian University students express admiration in six different situations.

According to Holmes (1986:485) a compliment is "a speech act which explicitly or implicitly attributes credit to someone other than the speaker, usually the person addressed, for some 'good' (possession, characteristic, skill etc.) which is positively valued by the speaker and the hearer". In most studies, compliments are considered as expressive speech acts with multiple functions. According to Kerbrat-Orecchioni (2005) compliments are "verbal gifts", offered to enhance the face of the recipient, to negotiate or affirm solidarity between speaker and hearer (Herbert, 1989, Holmes, 1988, etc.) and to encourage desired behavior in specific situations. Compliments also serve as intensification or indirect forms of speech acts such as apologizing, thanking, advising, asking for information, etc. or mitigating devices of face-threatening acts like criticism, reprimanding, etc. (Jaworski, 1995: 74). While compliments serve as conversation openers as well (Traverso, 1996: 107), they are also employed to mitigate face-threatening acts in written discourse (Gea Valor, 2000). Although compliments can generally be seen as positive politeness devices, they may more specifically be considered as examples of some of the positive politeness strategies developed by Brown and Levinson (1987: 102 - 128). As a matter of fact compliments function as "prime examples of the first positive politeness strategy, that is, 'Notice, attend to $\mathrm{H}$ (his interests, wants, needs, goods' [...] since complimenters indicate that they have noticed and attend to the recipients' needs and

\footnotetext{
${ }^{1}$ See the edited volume by Schneider \& Barron (2008), comprising studies on speech acts (requests, expression of gratitude, apologies, invitations, etc.) and other pragmatic phenomena (the use of address forms, response tokens, small talk, etc.) in the following pluricentric languages: Dutch, English, French, German, and Spanish.

${ }^{2}$ For details see Schneider \& Barron (2008).
} 
interests and attempt to make the addressee feel good" (Sifianou, 2001: 396). Compliments could also be interpreted as "the output of [the] second positive politeness strategy, that is, 'Exaggerate (interest, approval, sympathy with H)'" (ibid.) and this aspect is usually reflected in the use of intensifiers such as adverbs and interjections in compliment utterances. A compliment can also function as an example of strategy 7, that is, "Presuppose / raise / assert common ground", in the sense that the compliment indicates a kind of commonality with regard to taste, values, etc. Compliments may also function as examples of the last positive politeness strategy, that is, "Give gifts to H", which consists in offering goods, sympathy, understanding, cooperation, etc. In other words by giving a compliment, the speaker indicates that $\mathrm{s} /$ he knows "the addressee's 'human relation wants' to be liked and admired and tries to satisfy them" (ibid.). In brief, "irrespective of the particular strategy they are outputs of, compliments are clearly positive politeness devices" (ibid.: 398). Compliments also have negative politeness functions. This is the case when they are employed to mitigate face-threatening acts such as requests, criticism, etc.

\section{Research Questions}

Having established that compliments are examples of positive politeness and that their realizations and functions may differ across cultures, languages, and even regional varieties of the same language, the aim of the present study is to look at how admiration is expressed in Cameroon English and Canadian English. The research questions are:

- Does the compliment behaviour of Cameroonian and Canadian English-speaking University students differ with regard to the choice of direct and indirect compliments, simple and complex compliments?

- Are there any systematic similarities and differences concerning the frequency and types of lexical devices (e.g. adjectives, adverbs, verbs, nouns) appearing in the compliment utterances?

- Are there differences in the way participants of both groups use external modification devices or supportive moves in compliment utterances?

- Are there differences with regard to situational distributions of the above compliment strategies in both varieties of English?

\section{Method}

\subsection{Instrument and Procedure}

The instrument employed to elicit compliments responses was a Discourse Completion Task (DCT) questionnaire consisting of sixteen situations (eight situations for compliments eight for compliment response) in which either an interlocutor initiation (for the eight situations for compliment responses) or a rejoinder (for the other eight compliment situations) was provided. The present study focuses on six compliment situations ${ }^{3}$. Each situation comprised a brief

\footnotetext{
3 There was a significant difference in the number of responses provided by the Canadian and Cameroonian participants to two of the eight questionnaire situations were not equally distributed. We therefore decided not to consider both situations in this study.
} 
description setting "the general circumstances [...] and the relevant situational parameters concerning social dominance, social distance and degree of imposition" (Barron, 2008: 43). The students had to write what they would say in the given situations. The actual scenarios used were the following

a. Situation 1: Your boyfriend or girlfriend has just got a new hairstyle which suits them well. You like the hairstyle and you would like him or her to know.

You:

Your boyfriend or girlfriend: "Oh! Thanks for the compliment!"

b. Situation 2: You are invited to your friend's place. His/her parents ask you to stay for supper. After the meal that you particularly appreciated, what do you say to your friend's parents?

You:

Your friend's parents: "Thank you. That's so nice!"

c. Situation 3: You attend a soccer/hockey/basketball game and you are particularly impressed by the performance of one of the players. At the end of the game, you go to see the player in question to let him/her know of your admiration.

You:

The player: "Really? Thanks for coming to the game!"

d. Situation 4: During the summer vacation, your best friend and his/her parents moved. At the start of the school/academic year you pay them a visit and are particularly impressed by their new house. What do you say to your friend?

You:

Your friend: "It's not any nicer than yours."

e. Situation 5: Your teacher, about 30 years of age, is particularly nice to you. You often have the opportunity to chat with him/her after class. One day you meet him/her around the school or university campus and you notice that s/he is wearing a lovely shirt or dress.

You:

Your teacher: "Oh. That's nice of you to say."

f. Situation 6: A classmate of the opposite sex made an excellent presentation in class. You don't know him or her very well but you would like to tell them that they did an excellent job.

You:

Your classmate: "Thank you. It makes me really happy to hear that!"

\subsection{Participants}

Two groups of students participated in the study. The first group consisted of twenty-five (22 females and 3 males) students at Cape Breton University (Canada), in the age range of 18 to 26. These students were taking courses in degree programs in a range of disciplines offered by the institution. All the respondents were Canadian native speakers of English. The second group consisted of 25 (17 males and 8 females) students at the University of Buea, in the age range of 18 to 25 . These students were also enrolled in different degree programs offered by the institution. 


\subsection{Data Analysis}

In the answers provided by the respondents of both groups compliments appear either as head acts only, i.e. as minimal units employed to express admiration, as combinations of head acts and supportive moves (additional speech acts), or as supportive moves, i.e. as forms otherwise used to realized other kinds of speech acts but which are employed to offer compliments. The first step was to examine the compliment utterances in terms of their length and move structures, while taking into account the number of units involved in a compliment utterance. The compliments were analyzed as consisting of head acts only, as in (1), of combinations of head acts + supportive moves, as in (2), and of supportive moves only, as in (3).

1) I like your haircut!

2) Thanks for supper. It was really good.

3) Wouldn't you teach me to cook like you?

The next step was to look at patterns of head acts in order to determine whether the head acts are direct or indirect and whether the compliments consist of single head acts, as in (4), or multiple head acts, as in (5).

4) I had a wonderful meal!

5) Good game tonight, I was impressed with your skills.

The analysis of multiple head acts also focused on the number of head acts involved in the various combinations (double, triple, etc.). Another aspect of the study was to examine the lexical and syntactic / stylistic devices used in the head acts (internal modification). The attention here was given to devices used to explicit the positive connotation of the utterance or to augment its illocutionary force. We focused on lexical devices such as positively loaded adjectives, adverbs of intensity, complimentary verbs and positively loaded nouns as well as syntactic devices such as modal expressions, as in (6).

6) Girl, I must say congratulations for working so hard.

Finally, the use of supportive moves was examined. The intent of the analysis here was to determine the types and functions of additional speech acts employed before (pre-compliments) or after (post-compliments) the head acts. The analysis yielded the results presented in the next section.

\section{Results}

The results will be presented for each of the six questionnaire situations and for each of the aspects indicated above. As already mentioned the presentation will compare features from both data sets. 


\subsection{Situation 1: Complimenting a Close Friend on his/her New Haircut}

4.1.1 Move structure and head act strategies

Table 1 shows the frequency of the move structures and head act strategies in compliments in situation 1.

Table 1. Frequency of move structure and head act strategies in situation 1

\begin{tabular}{|c|c|c|c|}
\hline \multicolumn{2}{|c|}{ Move structure } & Cameroon & Canada \\
\hline $\begin{array}{l}\text { Head-acts } \\
\text { only }\end{array}$ & Single head acts & 11 & 1 \\
\cline { 2 - 4 } & Double head acts & 0 & 10 \\
\hline \multicolumn{2}{|c|}{ Head acts + supportive moves } & 13 & 14 \\
\hline \multicolumn{2}{|c|}{ Supportive moves only } & 1 & 0 \\
\hline \multicolumn{2}{|c|}{ Total } & 25 & 25 \\
\hline
\end{tabular}

As can be seen in Table 1 above, 'head acts only' realizations and 'head acts + supportive moves' occurrences are distributed equally in both data sets. One Cameroonian makes use of the 'supportive move only' strategy. With regard to the head act strategies, Table 1 shows that the Cameroonians used eleven single direct heads as in (7), and one indirect head as in (8), while the Canadians by far prefer direct double head acts as in (9).

7) You look cute in that hairstyle! ( $\mathrm{CamE}^{4}$, Hairstyle)

8) I realize I made the best choice. (CamE, Hairstyle)

9) I really like your haircut; it frames your face well. (CanE ${ }^{5}$, Hairstyle)

4.1.2 Lexico-semantic and stylistic devices in head acts

\subsubsection{Lexical devices}

With regard to this aspect, Table 2 reveals the frequency and percentage of lexical devices in compliments on friend's new hairdo by the participants of both groups.

\footnotetext{
${ }^{4}$ CamE means Cameroon English.

${ }^{5}$ CanE means Canadian English.
} 
Table 2. Lexical devices used in situation 1

\begin{tabular}{|c|c|c|}
\hline Lexical devices & Cameroon & Canada \\
\hline Adjectives & 22 & 18 \\
\hline Adverbs & 2 & 26 \\
\hline Verbs & 2 & 27 \\
\hline Total & 26 & 71 \\
\hline
\end{tabular}

Table 2 shows that the number of lexical devices in the Canadians compliments is higher than that in the Cameroonian compliments. While the three types of lexical devices are almost equally distributed in the Canadian corpus, the vast majority of the Cameroonian students favor the use of adjectives. The analysis also reveals diverging strategies in terms of types and frequency of the adjectives, adverbs and verbs. The Canadian University students employ adjectives such as good $\left(7^{6}\right)$, great (5), cute (2), perfect (1), mint (1), awesome (1), handsome (1), adverbs such as really (12), so (6), well (5), great (1), even more (1), way + adjective + than before (1), and verbs such as to like (13), to love (7), to suit (6), to frame (1). The use of lexical devices is seen in the following examples from the Canadian English data set:

10) Oh wow! You're new hairstyle is great and suits you so well! You look even more handsome now. (CanE, Hairstyle)

11) I really like your haircut; it frames your face well! (CanE, Hairstyle)

The Cameroonian students make use of adjectives such as cute (5), good (5), elegant (3), beautiful (3), handsome, (2), special (1), splendid (1), lovely (1), nice (1), one adverb, namely pretty (2) and two verbs: to envy (1), to love (1). The following examples illustrate the use of the lexical devices in compliments:

12) Oh my dear! Your hairstyle looks pretty beautiful! (CamE, Hairstyle)

13) I envy your hair style! (CamE, Hairstyle)

\subsubsection{Stylistic Devices}

The Cameroonians also employ comparative and superlative structures to intensify their compliments, as can be seen in the following examples:

14) You look like a queen / like a fifteen year old. (CamE, Hairstyle)

15) You are more beautiful / handsome now. (CamE, Hairstyle)

16) I made the best choice. (CamE, Hairstyle)

\footnotetext{
${ }^{6}$ The numbers in brackets represents the number of occurrences of each lexical device.
} 


\subsubsection{External Modification}

As regards the use of additional speech acts or supportive moves, Table 3 indicates that the same pre- and post-compliments are not found in both corpora.

Table 3. Frequency and types of supportive moves in situation 1

\begin{tabular}{|c|c|c|c|}
\hline & & Cameroon & Canada \\
\hline \multirow{4}{*}{ 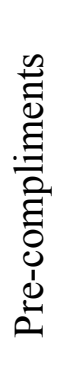 } & Interjections & 2 & 8 \\
\hline & Address forms / greetings & 13 & 3 \\
\hline & Exclamation / surprise & 0 & 1 \\
\hline & Questions & 0 & 2 \\
\hline \multirow{3}{*}{ 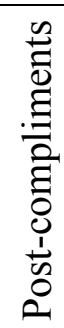 } & Advice & 0 & 2 \\
\hline & Comment & 0 & 1 \\
\hline & Surprise & 0 & 1 \\
\hline \multicolumn{2}{|r|}{ Total } & 15 & 18 \\
\hline
\end{tabular}

As can be seen in Table 3, while the Canadians employ pre- and post-compliments, the Cameroonian students only use pre-compliments. The most common pre-compliments in the Cameroonian data set are address forms and/or greetings, while the Canadian most frequently employ interjections before the compliments proper. The pre-compliments in the Canadian data set include interjections such as damn, ah, ooh, wow, oh my God, oh wow and oh, the address form and/or greeting formula hey, the expression of surprise you did your hair!, and questions such as did you get a new haircut lately? The post-compliment attested are advice, as in (17), comment, as in (18), and the expression of surprise as in (19).

17) You should get your hair cut like that more often. (CanE, Hairstyle)

18) Not many people can pull off short/long hair. (CanE, Hairstyle)

19) I didn't think that was possible (ha ha)!). (CanE, Hairstyle)

The Cameroonian respondents employ address forms such as baby, honey, sweetheart, love, boy, my dear) and interjections (oh). Two examples from the corpus are given below.

20) Darling you look more handsome now! (CamE, Hairstyle)

21) Sweetheart that's an elegant hair do. (CamE, Hairstyle) 


\subsection{Situation 2: Complimenting the Culinary Skills of Friend's Parents'}

4.2.1 Move structure and head act strategies

Table 4 shows the distribution (frequency) of head act strategies in situation 2.

Table 4. Frequency of move structures and head act strategies in situation 2

\begin{tabular}{|c|c|c|c|}
\hline \multicolumn{2}{|c|}{ Move structure } & Cameroon & Canada \\
\hline $\begin{array}{c}\text { Head } \\
\text { acts } \\
\text { only }\end{array}$ & Single head acts & 8 & 0 \\
\cline { 2 - 4 } & Double head acts & 0 & 0 \\
\hline Head acts + supportive moves & 15 & 24 \\
\hline Supportive moves only & 2 & 1 \\
\hline \multicolumn{2}{|c|}{ Total } & 25 & 25 \\
\hline
\end{tabular}

Table 4 shows that the Canadian informants do not employ the 'head act only' strategy, while this pattern occurs in the Cameroonians corpus, albeit in a much lower percentage compared to the 'head act + supportive move' strategy. The only example of indirect head in the Canadian corpus is the following expression of gratitude:

22) Thank you for the delicious meal! (CanE, Meal)

The utterance in (22) may be interpreted as an appreciation token with complimentary connotation, due to the positive loaded adjective 'delicious'. There are two examples of indirect compliments in the Cameroonian data set. They appear as a request for the recipe, as in (23) and a request for help in acquiring the complimented skills, as in (24).

23) Mama, can I have your recipe? (CamE, Meal)

24) Wouldn't you teach me to cook like you? (CamE, Meal)

\subsubsection{Lexico-Semantic and Stylistic Devices}

\subsubsection{Lexical Devices}

As Table 5 indicates, there are differences with regard to the frequency of lexical devices in both data sets. 
Table 5. Lexical devices used in compliments on culinary skills/meal

\begin{tabular}{|c|c|c|}
\hline Lexical devices & Cameroon & Canada \\
\hline Adjectives & 17 & 26 \\
\hline Adverbs & 5 & 8 \\
\hline Verbs & 3 & 6 \\
\hline Total & 25 & 40 \\
\hline
\end{tabular}

Table 5 shows that the Canadian employ more devices than their Cameroonian counterparts. While some similarities emerge with regard to the types of devices employed by respondents of both groups, the results also show some differences in terms of preference for some lexical devices. The Canadian respondents make use of the following lexical devices in their compliments on the addressee's culinary skills: Adjectives such as delicious (15), good (5), great (3), exceptional (1), tasty (1), beautiful (1); adverbs such as really (5), very (1), so (1), absolutely (1), and the verb to enjoy (6). The following examples illustrate the use of some of the lexical devices:

25) That was delicious, thanks for preparing a great meal. (CanE, Meal)

26) I am so grateful for supper. Thank you so much for this beautiful meal it was absolutely delicious. (CanE, Meal)

The Cameroonians employ adjectives such as delicious (4), appetizing (4), good (2), special (1), favourite (1), enjoyable (1), sumptuous (1), excellent (1), wonderful (1), nice (1); adverbs: very much (1), very (1), so (1), so well (1), always (1) and the verbs to enjoy (3). Representative examples from the data set are given below.

27) The dish is appetizing! (CamE, Meal)

28) What a sumptuous meal! (CamE, Meal)

29) You've always had the most appetizing dish I have ever eaten! (CamE, Meal)

\subsubsection{Stylistic Devices}

The Cameroonians also employ comparative structures and expressions of surprise in complimenting the addressee's culinary skills, as shown in the following examples.

30) Dad, I never knew you could cook so well! (CamE, Meal)

31) Mum, you are the best cook in the world! (CamE, Meal)

\subsubsection{External Modification}

Table 6 shows that, apart from differences regarding the overall frequency of attested 
supportive moves, the participants of both groups do not use the same external modification devices before and/or after their compliments.

Table 6. Frequency and types of supportive moves in situation 2

\begin{tabular}{|c|c|c|c|}
\hline & & Cameroon & Canada \\
\hline \multirow[t]{2}{*}{ Pre-compliments } & Address forms & 15 & 0 \\
\hline & Thanks & 0 & 20 \\
\hline \multirow{7}{*}{ 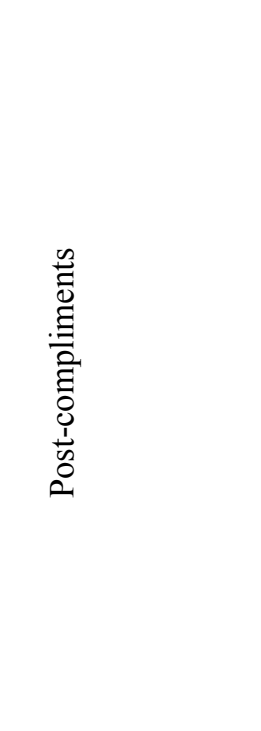 } & Thanks & 0 & 9 \\
\hline & Offering help & 0 & 3 \\
\hline & Request & 0 & 1 \\
\hline & Wish & 0 & 1 \\
\hline & Comment & 0 & 1 \\
\hline & Suggestion & 0 & 1 \\
\hline & Encouragement & 1 & 0 \\
\hline \multicolumn{2}{|r|}{ Total } & 16 & 36 \\
\hline
\end{tabular}

Table 6 indicates that pre-compliments are much more frequently employed than post-compliments in the Canadian corpus and all the pre-compliments are expressions of gratitude, as in (32)

32) Thanks so much for the supper. It was tasty! (CanE, Meal)

The Canadians make use of five different speech acts as post-compliments, with thanks being the most common. Three respondents offer help to clean up, as in (33). The other supportive moves, namely wish, as in (34), suggestion, as in (35), request and comment, as in (36), occurred in one instance respectively.

33) Thanks for the meal, it was delicious! Can I help you clean up? (CanE, Meal)

34) That was delicious, you make the best meals. I would love to know all your cooking secrets. (CanE, Meal)

35) Thank you for having me. The food was exceptional. I must come around more often. (CanE, Meal) 
36) I really enjoyed it. Would I be able to get the recipe sometime off of you? I think my parents would really enjoy it. (CanE, Meal)

As we can see in Table 6, the Cameroonian participants exclusively employ address forms (e.g. mama, mum) as pre-compliments. There is only one token of compliment post-modifier, namely the speech act of encouragement, as in (37).

37) Your dish is delicious keep it up! (CamE, Meal)

\subsection{Situation 3: Complimenting stranger's sports skills}

\subsubsection{Move Structure and Head Act Strategies}

Table 7 presents the frequency of move structures and head strategies in situation 3 .

Table 7. Move structures and head act strategies in situation 3

\begin{tabular}{|c|c|c|c|}
\hline \multicolumn{2}{|c|}{ Move structure } & Cameroon & Canada \\
\hline \multirow{3}{*}{ 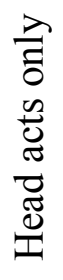 } & Single head acts & 17 & 3 \\
\hline & Double head acts & 0 & 7 \\
\hline & Triple head acts & 0 & 1 \\
\hline \multicolumn{2}{|c|}{ Head acts + supportive moves } & 7 & 14 \\
\hline \multicolumn{2}{|c|}{ Supportive moves only } & 1 & 0 \\
\hline \multicolumn{2}{|r|}{ Total } & 25 & 25 \\
\hline
\end{tabular}

It can be seen in Table 7 that the head act only strategy is by far the most frequently employed by the Cameroonians, while the Canadian most favor structures with the head act + supportive moves strategy. In the realization of the head acts only strategy the Canadians use single head acts, as in (38), double heads, as in (39), as well as triple heads, as in (40).

38) You played really well today. (CanE, Sports)

39) Played awesome today, it was great watching you. (CanE, Sports)

40) That was a wicked game. Excellent effort out there. Good team effort! (CanE, Sports)

The Cameroonians, by contrast, employ only single head acts, as in (41).

41) You are a very good player! (CamE, Sports)

There is one instance of the 'supportive move only' strategy in the Cameroonian corpus (a token of indirect compliment in the form of a wish), as in (42), and none in the Canadian data. 
42) I wish to have such a talent as yours! (CamE, Sports)

\subsubsection{Lexico-Semantic and Stylistic Devices}

\subsubsection{Lexical Devices}

As can be seen in Table 8, speakers of Canadian English use more lexical devices than speakers of Cameroon English.

Table 8. Distribution of lexical devices in situation 3

\begin{tabular}{|c|c|c|}
\hline Lexical devices & Cameroon & Canada \\
\hline Adjectives & 12 & 29 \\
\hline Adverbs & 7 & 20 \\
\hline Verbs & 3 & 3 \\
\hline Total & 22 & 52 \\
\hline
\end{tabular}

Apart from statistical differences, the study of the types of devices used reveals some interesting results with regard to the preference for certain adjectives and adverbs by the respondents of both groups. The Canadian students use the following devices to explicit and/or reinforce their compliments: Adjectives such as great (8), good (8), awesome (6), excellent (2), impressed (2), wicked (1), interesting (1), incredible (1), smart (1); adverbs such as really (7), (play) awesome (4), well (3), probably (1), very (1), always (1), so (1), (play) amazing (1), (play) sick (1); verbs such as to like (1), to enjoy (1), to admire (1). Semantic shifts and change of category of some lexical items are attested in the Canadian English data set. The adjective wicked for instance is used with a positive connotation to reinforce compliments. This is also the case with sick which is employed in a positive sense and as an adverb of intensity. We also notice that awesome and amazing occur as adverbs. Illustrative examples from the corpus are given below.

43) That was a wicked game. (CanE, Sports)

44) Wow! You played awesome, your one of the best I've seen play in a while. (CanE, Sports)

The Cameroonians employed the following lexical devices in their compliments: Adjectives such as great (4), good (2), surprised (1), proud (1), wonderful (1), encouraging (1), skillful (1), pleased (1); adverbs such as just like (2), indeed (1), well (1), excellently (1), extremely well (1), very (1); and verbs such as to enjoy (2), and to like (1). Some examples from the Cameroon English corpus are shown below.

45) The way you play handball makes me proud. (CamE, Sports)

46) Hello, you played extremely well! (CamE, Sports) 


\subsubsection{Stylistic Devices}

The analysis also reveals that both Cameroonians and Canadians make use of stylistic devices to mitigate or intensify their compliments. In the Canadian data set, there are three occurrences of the combination just + tense in the expression I just wanted to tell you that, which serves to introduce and mitigate the compliment, as in (47). Also attested is the expression I had to tell you that which is employed to intensify the sincerity of the compliment, as in (48). The Canadians also employ superlative constructions, as in (49).

47) Hey, I just wanted to tell you that you did a really good job! That was an awesome game! (CanE, Sports)

48)I had to tell you that you were awesome out there. (CanE, Sports)

49) I loved watching you play today. You always seem to make the smartest plays. (CanE, Sports)

The results also reveal that Cameroonians also make use of stylistic devices to mitigate their compliments. But, contrary to the Canadians, the Cameroonian participants use the marker of subjectivity I think, as in (50).

50) I think you are not doing bad in football! (CamE, Sports)

Strategies employed to intensify the compliments are mostly expressions of surprise such as $I$ never believed, as in (51) and I never knew, as in (52). Another device employed to reinforce the sincerity of the compliment is the expression I must say, as in (53). Finally, in order to highlight the quality of the addressee's skills, some Cameroonians use the comparative structure containing just like, as in (54), as well as the superlative expression one in a million, as in (55).

51) I never believed you could be so skillful until today! (CamE, Sports)

52) I never knew you can play football! (CamE, Sports)

53) Girl, I must say you performed excellently! (CamE, Sports)

54) Wow! You play just like Zidane! (CamE, Sports)

55) Brian, the dribble was one in a million. (CamE, Sports)

\subsubsection{External Modification}

Table 9 reveals that the respondents of both groups have quite different preferences with regard to the use of supportive moves. 
Table 9. Frequency and types of supportive moves in situation 3

\begin{tabular}{|c|c|c|c|}
\hline & & Cameroon & Canada \\
\hline \multirow{4}{*}{ 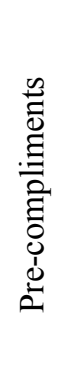 } & Address forms / greetings & 5 & 5 \\
\hline & Interjections & 1 & 2 \\
\hline & Comments & 0 & 1 \\
\hline & Apology & 0 & 1 \\
\hline \multirow{5}{*}{ 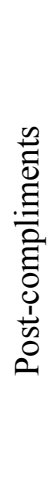 } & Wish & 0 & 2 \\
\hline & Advice & 0 & 2 \\
\hline & Comments & 0 & 2 \\
\hline & Joy & 0 & 1 \\
\hline & Encouragement & 1 & 0 \\
\hline & Total & 7 & 16 \\
\hline
\end{tabular}

As can be seen in Table 9, the Canadians employ nine pre-compliments, namely the interjection wow, greetings / address forms (e.g. hey), and an apology, as in (56), comments, as in (57). The post-compliments appear in form of expressions of wish, as in (58), comments, as in (59), advice, as in (60), and expressions of joy, as in (61).

56) Hey. I don't mean to sound creepy but I was watching you play all throughout the game and I really admire your abilities. (CanE, Sports)

57) Hey, I have been watching you play all game and I really like some of the tricks you have done. (CanE, Sports)

58) I really like some of the tricks you have done to get around the players. I wish someday I will be able to play as well as what you do. (CanE, Sports)

59) Hey! You did amazing tonight. Just thought I should let you know. (CanE, Sports)

60) Wow, you really played well today, you should go professional. (CanE, Sports)

61) You played a very interesting game. I'm glad I came and watched your performance. (CanE, Sports)

The Cameroonians use supportive moves in a much lower percentage than the Canadians. 


\section{Macrothink}

International Journal of Linguistics

ISSN 1948-5425

2013, Vol. 5, No. 3

The following items occur as pre-compliments: address forms (Girl, Brian), interjection (wow), and greetings such as Hi, Hi there, Hello. The only token of post-compliment is the speech act of encouragement, as in (63).

62) Hi there! Your talent is great! (CamE, Sports)

63) That's great, keep up! (CamE, Sports)

\subsection{Situation 4: Complimenting a friend's (parents') house/apartment}

\subsubsection{Move Structure and Head Act Strategies}

Table 10 gives a breakdown of the move structure and head act strategies in both corpora.

Table 10. Move structures and head act strategies in situation 4

\begin{tabular}{|c|c|c|c|}
\hline \multicolumn{2}{|c|}{ Move structure } & Cameroon & Canada \\
\hline \multirow{2}{*}{$\begin{array}{l}\text { Head } \\
\text { acts } \\
\text { only }\end{array}$} & Single head acts & 18 & 3 \\
\cline { 2 - 4 } & Double head acts & 0 & 3 \\
\hline Head acts + supportive moves & 5 & 19 \\
\hline Supportive moves only & 2 & 0 \\
\hline Total & 25 & 25 \\
\hline
\end{tabular}

As can be seen in Table 10, the Canadians produce more occurrences of the 'head acts + supportive' strategy than those of the 'head acts only' strategy, whereas the Cameroonians by far prefer the 'head acts only' strategy in the realization of their compliments. While the Canadians realize single head acts, as in (64), and double head acts, as in (65), the Cameroonians exclusively use single head acts, as in (66). Two Cameroonians realize their compliments indirectly, using a jocular question, as (67) and a positively intended comment, as in (68). There is no indirect compliment in the Canadian data set.

64) I really like your new place. (CanE, House)

65) Your new house looks so great. It's really pretty! (CanE, House)

66) Your house is well designed! (CamE, House)

67) Where were all these hiding (With a smile)? (CamE, House)

68) There is a complete change! (CamE, House) 


\section{Macrothink}

\subsubsection{Lexico-Semantic and Stylistic Devices}

\subsubsection{Lexical Devices}

With regard to the use of lexical devices, Table 11 illustrates that the Canadians employ more tokens than the Cameroonians do.

Table 11. Lexical devices used in situation 4

\begin{tabular}{|c|c|c|}
\hline Lexical devices & Cameroon & Canada \\
\hline Adjectives & 20 & 29 \\
\hline Adverbs & 5 & 22 \\
\hline Verbs & 3 & 11 \\
\hline Total & 28 & 62 \\
\hline
\end{tabular}

Differences are also found with regard to the types of adjectives, adverbs and verbs. The lexical devices found in the compliments of the Canadians include adjectives such as nice (5), beautiful (5), amazing (3), pretty (2), awesome (2), jealous (2), cool (1), clean (1), big (1), unreal (1), great (1), spacious (1), good (1), lucky (1), sweet (1), similar (1); adverbs such as so (9), really (8), kinda / kind of (2), totally (1), nicely (1), absolutely (1) and verbs such as to love (7) and to like (4). The adverb kind of is used to soften the negative component of the adjective jealous. Some typical examples from the corpus are given below.

69) Wow your house looks so nice. I'm kinda jealous. (CanE, House)

70) I love your new house, it's really spacious. It would be nice to have a house this big. (CanE, House)

The Cameroonian participants use adjectives such as nice (4), wonderful (3), cute (2), good (2), well furnished (2), jealous (1), well designed (1), beautiful (1), charming (1), lovely (1), well arranged (1), complete (1); adverbs such as so (1), so much (1), such (1), very (1), really (1) and verbs such as to admire (2) and to love (1). Representative examples are shown in the samples below.

71) Your room is well furnished and arranged. (CamE, House)

72) It's really nice to live in! (CamE, House)

\subsubsection{Stylistic Devices}

The Canadians employ comparative constructions with the expression way + comparative form of adjective + than (e.g. way better than) to reinforce their compliments, as in (73), while the Cameroonians make use of metaphoric expressions to intensify their compliments, as in (74). 
73) Wow your new house is way better than your old house and my house. (CanE, House)

74) You're in Paradise on Earth! You are living in paradise! (CamE, House)

\subsubsection{External Modification}

Table 12 presents the distribution (frequency) and types of supportive moves in both data sets. It can be seen that the Canadian are by far much more productive than the Cameroonians.

Table 12. Frequency and types of supportive moves in situation 4

\begin{tabular}{|c|c|c|c|}
\hline & & Cameroon & Canada \\
\hline \multirow{4}{*}{ 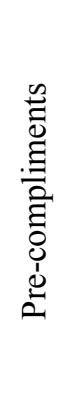 } & Address forms & 5 & 0 \\
\hline & Interjections & 0 & 13 \\
\hline & Regret / sadness & 0 & 1 \\
\hline & Question & 0 & 1 \\
\hline \multirow{5}{*}{ 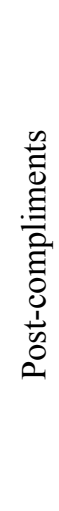 } & Comment & 0 & 5 \\
\hline & Question & 0 & 1 \\
\hline & Wish & 0 & 1 \\
\hline & Promise / commitment & 0 & 1 \\
\hline & Regret / sadness & 0 & 1 \\
\hline \multicolumn{2}{|r|}{ Total } & 5 & 24 \\
\hline
\end{tabular}

Table 12 shows that the Canadians with interjections (e.g. wow, damn, oh wow, oh man), expressions of regret/sadness, as in (75), and questions, as in (76), to introduce their compliments. They also employ five different speech acts as post-compliments, namely comments, as in (77), the expression of wish, as in (78), a promise or commitment, as in (79), and the expression of sadness that the recipient had to move, as in (80).

75)It sucks that you had to move, but your house is awesome! That is at least one positive thing. (CanE, House)

76) Do you love your new house? It's so nice! (CanE, House) 
77) Your new house is amazing! There is so much room than your old house. (CanE, House)

78) I love your new house, it's really spacious. It would be nice to have a house this big. (CanE, House)

79) This house is really great, it is so nice. Your so lucky! I'll have to come visit more often. (CanE, House)

80) Oh wow! You're new house is beautiful, I absolutely love it but of course I miss you guys so much. (CanE, House)

The Cameroonian respondents exclusively use pre-compliments, namely terms of endearment such as honey, baby, darling, as in (81).

81) Baby, I admire your room so much! (CamE, House).

4.5 Situation 5: Complimenting a superior's (teacher/professor) outfit

4.5.1 Move Structure and Head Act Strategies

Table 13. Move structure and head act strategies in situation 5

\begin{tabular}{|c|c|c|c|}
\hline \multicolumn{2}{|c|}{ Move structure } & Cameroon & Canada \\
\hline \multirow{2}{*}{$\begin{array}{l}\text { Head } \\
\text { acts } \\
\text { only }\end{array}$} & Single head acts & 5 & 3 \\
\cline { 2 - 4 } & Double head acts & 1 & 5 \\
\cline { 2 - 4 } & Triple head acts & 0 & 1 \\
\hline \multicolumn{2}{|c|}{ Head acts + supportive moves } & 19 & 16 \\
\hline \multicolumn{2}{|c|}{ Total } & 25 & 25 \\
\hline
\end{tabular}

Table 13 indicates that the participants of both groups employ more occurrences of the 'head acts + supportive' strategy than tokens of the 'head acts only' strategy. Within the latter strategy, the Canadians use more double head acts, as in (82), than single heads, as in (83), and triple heads, as in (84). The Cameroonians, by contrast, employ two patterns, double heads, as in (85) and single heads, as in (86).

82) You are wearing a lovely outfit today. You have great sense in style. (CanE, Outfit)

83) That shirt is awesome! (CanE, Outfit)

84) Your dress is really pretty - I love the colour. It looks really nice on you. (CanE, Outfit)

85) You are so gentle in it! I like your suit! (CamE, Outfit) 
86) You look good today in that new suit! (CamE, Outfit)

\subsubsection{Lexico-Semantic and Stylistic Devices}

\subsubsection{Lexical Devices}

As can be seen in Table 14, the Canadians are almost twice more productive than the Cameroonians with regard to the use of lexical devices in compliments on superior's outfit.

Table 14: Distribution of lexical devices in situation 5

\begin{tabular}{|c|c|c|}
\hline Lexical devices & Cameroon & Canada \\
\hline Adjectives & 13 & 26 \\
\hline Adverbs & 6 & 22 \\
\hline Verbs & 14 & 17 \\
\hline Total & 33 & 65 \\
\hline
\end{tabular}

There are some similarities and differences concerning the types and frequency of adjectives, adverbs and verbs employed in this situation. The Canadian students make use of the following devices: Adjectives such as nice (8), pretty (5), great (4), lovely (2), good (2), optimistic (1), fine (1), awesome (1), beautiful (1), and cute (1); adverbs such as really (14), very (4), well (2), so (1) and such (1); and verbs such as to like (10), to love (6) and to suit (1). The following examples are taken from the corpus.

87) Oh! You look lovely today. Very optimistic at this time of year for the weather. The colour looks great on you. (CanE, Outfit)

88) Oh, that's such a cute top! (CanE, Outfit)

The Cameroonians use adjectives such as good (5), well dressed (2), wonderful (1), attractive (1), gentle (1), nice (1), cute (1), smart (1); adverbs such as well (2), so (2), very (2), and verbs such as to like (8), to fit (4), to enjoy (1), and to admire (1). The following examples illustrate the use of lexical devices in the Cameroon English data set.

89) Sir, you are so well dressed! (CamE, Outfit)

90) I like your suit! You are so gentle in it! (CamE, Outfit)

\subsubsection{External Modification}

Table 15 presents the distribution and types of external modification devices in both varieties of English 
Table 15. Frequency and types of supportive moves in situation 5

\begin{tabular}{|c|c|c|c|}
\hline & & Cameroon & Canada \\
\hline \multirow{3}{*}{ 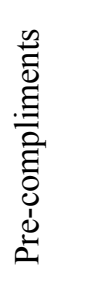 } & Greetings / Address forms & 19 & 10 \\
\hline & Interjections & 0 & 4 \\
\hline & Comment & 0 & 1 \\
\hline \multirow{2}{*}{ 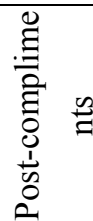 } & Questions & 0 & 2 \\
\hline & Comment & 0 & 1 \\
\hline \multicolumn{2}{|r|}{ Total } & 19 & 18 \\
\hline
\end{tabular}

Table 15 shows that, the Cameroonians only use pre-compliments, whereas the Canadians make use of pre- and post-compliments. There are tokens of three different types of pre-compliments in the Canadian data set, namely interjections such as oh, eh, wow, address forms such as Mrs, Miss, Mr and Ms and/or greeting formulas such as hi, hey, hey hello, and comment, as in (91). The post-compliments appear in the form of questions, as in (92) and comments, as in (93). All the supportive moves found in the Cameroonian data belong to the category of pre-compliments. The respondents employ address forms (terms of respect such as Sir, Madam, boss), as in (94), some of which are combined with greetings, as in (95).

91) Hello! Just thought you should know. I really like your dress. (CanE, Outfit)

92) I really like the new shirt/dress, where did you get it? (CanE, Outfit)

93) Your dress is so nice on you. I've seen it in other colors. (CanE, Outfit)

94) Sir, I admire you in your suit! (CamE, Outfit)

95) Hi, madam your clothes are really attractive! (CamE, Outfit)

The analysis of the pre-compliments indicates a major difference in the use of address forms: while the Canadians mostly employed terms of respect such as Mrs/Ms/Miss alone or in combination with greeting formulas such as hey, hello or with the interjection eh, the Cameroonians mostly prefer the term sir.

\subsection{Situation 6: Complimenting a Classmate's (oral) Presentation}

\subsubsection{Move Structure and Head Act Strategies}

Table 16 shows the distribution of move structures and head act strategies in both data sets. 
Table 16. Move structure and head act strategies in situation 6

\begin{tabular}{|c|c|c|c|}
\hline \multicolumn{2}{|c|}{ Move structure } & Cameroon & Canada \\
\hline \multirow{2}{*}{$\begin{array}{l}\text { Head } \\
\text { acts } \\
\text { only }\end{array}$} & Single head acts & 11 & 4 \\
\cline { 2 - 4 } & Double head acts & 0 & 10 \\
\cline { 2 - 4 } & Triple head acts & 0 & 1 \\
\hline \multirow{2}{*}{ Head acts + supportive moves } & 9 & 10 \\
\hline \multirow{2}{*}{ Supportive moves only } & 5 & 0 \\
\hline & Total & 25 & 25 \\
\hline
\end{tabular}

It can be seen in Table 16 that the Canadians use much more tokens of the 'head acts only' strategy than the Cameroonians. The 'supportive move only' strategy is attested only in the Cameroonian data set. The use of the 'head acts + supportive move' strategy is almost equally distributed in both corpora. There are major differences regarding the head act strategies. While the Cameroonians predominantly use single heads, as in (96), the Canadians offer compliments in form of single heads, as in (97), double heads, as in (98), and triple heads, as in (99). Five Cameroonian students compliment indirectly, using a jocular or rhetorical question, as in (100), expressions of surprise, as in (101), and expressions of wish, as in (102).

96) I enjoyed your presentation! (CamE, Presentation)

97) You did a really good job on your presentation. (CanE, Presentation)

98) You presented your material really well! I really enjoyed it! (CanE, Presentation)

99) You did a great job, it was very informative. Well done! (CanE, Presentation)

100) Why are you very intelligent? (CamE, Presentation)

101) Were you this talented? (CamE, Presentation)

102) I wish I was a genius like you! (CamE, Presentation)

\subsubsection{Lexico-Semantic and Stylistic Devices}

\subsubsection{Lexical Devices}

Table 17 reveals that the Canadians are more productive in the use of lexical devices than their Cameroonian counterparts. 
Table 17. Distribution of lexical devices in situation 6

\begin{tabular}{|c|c|c|}
\hline Lexical devices & Cameroon & Canada \\
\hline Adjectives & 17 & 21 \\
\hline Adverbs & 7 & 30 \\
\hline Verbs & 5 & 9 \\
\hline Positive loaded nouns & 2 & 0 \\
\hline Total & 31 & 60 \\
\hline
\end{tabular}

Apart from the statistical differences mentioned above, noteworthy differences also emerge with regard to the types of lexical elements found in both corpora. The Canadians employ more adverbs than adjectives whereas the Cameroonians make use of more adjectives than adverbs. The Canadians employ the following lexical items in compliments on the recipient's presentation: Adjectives such as great (10), good (2); informative (1); awesome (1); interesting (1); wonderful (1), confident (1); eye opening (1); excellent (1) comfortable (1); adverbs such as really (18), well (7), very (4), and a lot (1), and verbs such as to like (4), to enjoy (3), to stand out ${ }^{7}$ (1), and to make somebody think (1). The following examples are taken from the Canadian English data set.

103) You did a great job, it was very informative. Well done! (CanE, Presentation)

104) Great job today with your presentation, you really stood out. (CanE, Presentation)

The Cameroonians use the following items: Adjectives such as intelligent (6), good (3), bright (1), excellent (1), lucky (1), clever (1), hardworking (1), great (1), splendid (1), and talented (1); adverbs such as so (4), very (2), and this ${ }^{8}$ (1); and verbs such as to enjoy (2), to admire (1), to envy (1), and to appreciate (1). The Cameroonian participants also employ positively loaded nouns such as intellectual (1) and genius (1). Some illustrative examples from the corpus are presented below.

105) You are very hardworking, DG. (CamE, Presentation)

106) You are an intellectual! (CamE, Presentation)

107) I wish I was a genius like you! (CamE, Presentation)

\footnotetext{
7 This verb is used in the sense of "to perform much better than any other person in the class".

${ }^{8}$ This device is employed as a marker of insistence / intensity and could be replace with so, as in Hi, were you this talented? (CamE, Presentation).
} 


\subsubsection{Stylistic Devices}

The Cameroonians use the marker of subjectivity I think to soften the compliments, as in (108). Some of them prefer intensification devices, more precisely the expression of wish or desire I wish, as in (109), of surprise I never knew, as in (110), and of sincerity I must say, as in (111).

108) I think you are intelligent enough for my liking! (CamE, Presentation)

109) I wish I could present as you did! (CamE, Presentation)

110) I never knew you were so clever! (CamE, Presentation)

111) Girl, I must say congratulations for working so hard! (CamE, Presentation)

\subsubsection{External Modification}

Table 18 presents the distribution and types of supportive moves in both data sets.

Table 18. Frequency and types of supportive moves in situation 6

\begin{tabular}{|c|c|c|c|}
\hline & & Cameroon & Canada \\
\hline \multirow{6}{*}{ 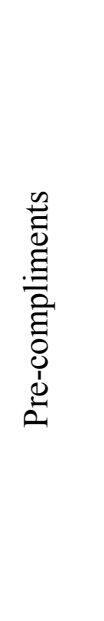 } & Greetings / Address forms & 5 & 6 \\
\hline & Interjections & 1 & 1 \\
\hline & Apology & 0 & 1 \\
\hline & Self-Introduction & 0 & 1 \\
\hline & Wish & 1 & 0 \\
\hline & Encouragement & 1 & 0 \\
\hline \multirow{2}{*}{ 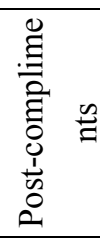 } & Comments & 0 & 4 \\
\hline & Encouragement & 1 & 0 \\
\hline \multicolumn{2}{|r|}{ Total } & 9 & 13 \\
\hline
\end{tabular}

It can be seen in Table 18 that the Canadians employ pre-compliments, mostly greetings such as Hey and $H i$, and address form and greeting, as in (112) or a combination of greetings, apology and self-introduction, as in (113). All instances of post-compliments in the Canadian data are comments, which are used to strengthen the compliment proper, as shown in (114).

112) Hey "name", you did really well. (CanE, Presentation) 
113) Hey! I don't know you very well but my name is (introduce self) and I just wanted you to know that you did an excellent job on your presentation). (CanE, Presentation)

114) You did a wonderful job on your presentation, I liked that you talked about that topic, people have to be more aware of it. (CanE, Presentation)

The use of supportive moves in the Cameroonian corpus is a bit different. The pre-compliments include an interjection (oh), address forms such as Girl, Young lady, DG as in (115), greetings, as in (116), an expression of wish, as in (117), an encouragement, as in (118). The only post-compliment is the speech acts of encouragement, as in (119)

115) Young lady, that was excellent of you! (CamE, Presentation)

116) $\boldsymbol{H i}$, the presentation was splendid! (CamE, Presentation)

117)I wish you were my brother, that notwithstanding, you are bright. (CamE, Presentation)

118) Courage, I admire the way you work! (CamE, Presentation)

119) It is good, keep up! (CamE, Presentation)

\section{Discussion and Conclusion}

The aim of this study was to examine compliment strategies by Canadian and Cameroonian English-speaking University students.

The first research question concerned the choices of the respondents of both groups with regard to the move structure and the head act strategies in compliment utterances. As can be seen in Table 19, the results reveal some similarities and differences.

Table 19. Overall frequency of move structures and head act strategies

\begin{tabular}{|c|c|c|c|c|c|}
\hline \multirow{2}{*}{\multicolumn{2}{|c|}{ Move structure }} & \multicolumn{2}{c|}{ Cameroon } & \multicolumn{2}{c|}{ Canada } \\
\cline { 2 - 5 } & No. & $\%$ & No. & $\%$ \\
\hline \multirow{2}{*}{$\begin{array}{l}\text { Head } \\
\text { acts only }\end{array}$} & Single head acts & 70 & 46.67 & 14 & 9.33 \\
\cline { 2 - 6 } & Double head acts & 1 & 0.67 & 35 & 23.33 \\
\cline { 2 - 6 } & Triple head acts & 0 & 0 & 3 & 2 \\
\hline \multirow{2}{*}{ Head acts + supportive moves } & 68 & 45.34 & 97 & 64.67 \\
\hline \multicolumn{2}{|c|}{ Supportive moves only } & 11 & 7.33 & 1 & 0.67 \\
\hline \multicolumn{2}{|c|}{ Total } & 150 & 100 & 150 & 100 \\
\hline
\end{tabular}




\section{$\triangle$ Macrothink}

Table 19 shows that while the 'head acts only' and the 'head acts + supportive' strategies are equally distributed in the Cameroonians corpus the Canadians employ the latter strategy much more than the former. Within the 'head acts only' strategy the Cameroonians show a very strong preference for single heads whereas the Canadians mostly favor double heads. Also, some Canadian offer compliments in form of triple heads. There is, by contrast, no instance of a triple head in the Cameroonian data set. The results also reveal that the Canadian participants use the 'head acts + supportive moves' strategy much more than their Cameroonian counterparts. Finally, the Cameroonian produce more compliments employing the 'supportive moves' strategy than the Canadians. In other words, the Cameroonians use indirect compliments much more than the Canadians.

The second research question concerned the use of internal modification devices. The four types of lexical devices which occur in the compliments are adjectives, adverbs, verbs and positively loaded nouns, as can be seen in Table 20 .

Table 20. Overall distribution of lexical devices

\begin{tabular}{|c|c|c|c|c|}
\hline \multirow{2}{*}{ Lexical devices } & \multicolumn{2}{|c|}{ Cameroon } & \multicolumn{2}{c|}{ Canada } \\
\cline { 2 - 5 } & No. & $\%$ & No. & $\%$ \\
\hline Adjectives & 101 & 61.21 & 149 & 42.57 \\
\hline Adverbs & 32 & 19.39 & 128 & 36.57 \\
\hline Verbs & 30 & 18.18 & 73 & 20.86 \\
\hline Positive loaded nouns & 2 & 1.21 & 0 & 0 \\
\hline Total & 165 & 100 & 350 & 100 \\
\hline
\end{tabular}

First, Table 20 shows that the Canadians produce more adjectives, adverbs, and verbs than the Cameroonians. In the Cameroon English data set, more than half of the tokens are adjectives, while adverbs and verbs are almost equally distributed. In the Canadian corpus, by contrast, although adjectives are the dominant lexical devices in compliments, their percentage is not as high as that of adjectives in the Cameroonian data set. Also, there is a significant quantitative difference between adverbs and verbs in the Canadian compliments. Qualitative differences also emerge from the analysis. The Canadian employ 37 different adjectives (namely good / better, great, cute, perfect, mint, awesome, handsome, delicious, exceptional, tasty, beautiful, excellent, impressed, wicked, interesting, incredible, smart, nice, amazing, pretty, jealous, cool, clean, big, unreal, spacious, lucky, sweet, similar, lovely, optimistic, fine, informative, wonderful, confident, eye opening, comfortable) of which the two most frequently employed are great (31 tokens out of 149 , i.e. $20.81 \%$ ) and good (25 instances out of 149 , i.e. $16.78 \%$ ). The Canadians also make use of 18 different adverbs 
(namely: absolutely, a lot, really, so, well, great, even more (+ adjective), way + adjective + than before, very, (play) awesome, probably, always, (play) amazing, (play) sick, kinda / kind of, totally, nicely, such.), with really (64 tokens out of 128, i.e. 50\%) so (18 examples out of 128 , i.e. $14.06 \%)$ and well (17 instances out of 128, i.e. $13.28 \%)$ appearing as the three most favored. Finally, 8 different verbs are attested in the Canadian corpus (namely: to like, love, suit, frame, enjoy, admire, stand out, make somebody think) and the respondents mostly prefer to like (32 instances out of 73, i.e. 43.84\%) and to love (20 examples out of 73, i.e. $27.40 \%$ ). The Cameroonians make use of the following adjectives: appetizing, attractive, beautiful, bright, charming, clever, complete, cute, delicious, elegant, encouraging, enjoyable, excellent, favourite, gentle, good, great, handsome, hardworking, intelligent, jealous, lucky, lovely, nice, pleased, proud, special, skillful, smart, splendid, sumptuous, surprised, talented, well arranged, well designed, well dressed, well furnished, wonderful, of which good (19 tokens out of 101 , i.e. $18.81 \%$ ) and cute (8 examples out of 101 , i.e. $7.92 \%$ ). The low percentage of these adjectives, in comparison to the two most common adjectives in the Canadian data set, is due to the fact that most of the adjectives in the Cameroonian compliments seem to be equally distributed across the situations and most of them are specific to the complimented object (e.g. delicious and appetizing respectively occur four times in compliments on a meal while elegant, beautiful and handsome are employed at least twice in compliments on the recipient's new hair cut). The Cameroonian participants employ the following adverbs: always, excellently, extremely, indeed, just like, much, pretty, really, so, such, this ${ }^{9}$, very, well, of which so (10 examples out of 32, i.e. $\left.31.25 \%\right)$ is by far the most preferred. The other adverbs appear with very low percentages. Some of the adverbs occur in combinations (e.g. very much, so well, extremely well, so much). The following verbs are attested in the Cameroonian compliments: to envy, love, enjoy, like, admire, fit, appreciate, and to like (9 examples out 30, i.e. $30 \%$ ) and to enjoy (6 instances out of 30 , i.e. $20 \%$ ) are the most frequently used. Finally, two Cameroonians employ the following positively loaded nouns in their compliments: intellectual (e.g. You are an intellectual!), genius.

The third research question dealt with the use of supportive moves. As can be seen in Table 21, the Canadians use much more external modification devices than the Cameroonians. Although pre-compliments are more frequently employed than post-compliments in both data sets, the Cameroonian participants almost exclusively use pre-compliments whereas there are $65.60 \%$ of pre-compliments and $34.40 \%$ of post-compliments in the Canadian English data. It was also found that the vast majority of pre-compliments in the Cameroonian corpus are address forms / greetings (62 tokens out of 68, i.e. 91.18\%) while the Canadian respondents mostly use three different types of pre-compliments, namely interjections (28 examples out of 82 , i.e. $34.17 \%$ ) greetings / address forms (24 instances out of 82, i.e. $29.27 \%$ ) and thanks (20 occurrences out of 82 , i.e. $24.39 \%$ ). In the Cameroonian data, the majority of the pre-compliments (address forms / greetings) are found in compliments on the professor's outfit (19 tokens; situation 5) whereas the Canadians mostly employ pre-compliments in compliments on a meal (20 instances, situation 2 ). With regard to the types of speech acts

\footnotetext{
9 A typical example from the corpus: $H$ i, were you this talented?
} 
employed as post-compliments, the results also reveal the Canadians to be more productive than the Cameroonians. As a matter of fact, while only three different speech acts appear as post-compliments in the Cameroon English data set, the Canadians use ten different speech acts, of which comments are the most common (14 examples out of 43, i.e. $32.56 \%$ ), after the head acts.

Table 21. Overall distribution of supportive moves

\begin{tabular}{|c|c|c|c|c|}
\hline \multirow{2}{*}{$\begin{array}{c}\text { Type of external } \\
\text { modification }\end{array}$} & \multicolumn{2}{|c|}{ Cameroon } & \multicolumn{2}{c|}{ Canada } \\
\cline { 2 - 5 } & No. & $\%$ & No. & $\%$ \\
\hline Pre-compliments & 68 & 95.77 & 82 & 65.60 \\
\hline Post-compliments & 3 & 4.23 & 43 & 34.40 \\
\hline Total & 71 & 100 & 125 & 100 \\
\hline
\end{tabular}

The prime purpose of this study was to contribute to a growing body of research in regional pragmatic variation, and it looked at the complimenting behavior of a small group of English-speaking Canadian and Cameroonian University students. As such, it is too early to draw conclusions with regards to students' choices in both regions with regard to compliment patterns. Also, the results obtained may not apply to all English-speaking Canadians and Cameroonians. It would therefore be interesting to examine a larger corpus and other types of data (e.g. naturally-occurring conversations) from students, other groups of participants, and situations in order to capture quantitative and qualitative differences and similarities in the ways English-speaking Canadians and Cameroonians express admiration. This may also be undertaken by looking at compliment response strategies in both varieties of English.

\section{References}

Barron, A. (2005). Offering in Ireland and England. In A. Barron, \& Klaus Peter, Schneider (eds.), The pragmatics of Irish English (pp. 141-176). Berlin / New York: Mouton de Gruyter.

Barron, A. (2008). The structure of requests in Irish English and English. In K. P. Schneider \& A. Barron (eds.), Variational Pragmatics. A Focus on Regional Varieties in Pluricentric Languages (pp. 35-67). Amsterdam/Philadelphia: John Benjamins.

Brown, P., \& Levinson, S. C. (1987). Politeness: Some Universals in Language Usage. Cambridge: Cambridge University Press.

Gea Valor, M. L. (2000). A Pragmatic Approach to Politeness and Modality in Book Reviews. Valencia: SELL Monograph.

Golato, A. (1995). Compliments and compliment responses. Grammatical structures and sequential organization. Amsterdam / Philadelphia: John Benjamins Publishing Company. 
Herbert, R. K. (1989). The ethnography of English compliments and compliment responses: A contrastive sketch. In W. Oleksy (Ed.), Contrastive pragmatics (pp. 3-35). Amsterdam: John Benjamins,

Holmes, J. (1986): Compliments and compliment responses in New Zealand English. Anthropological Linguistics, 28(4), 485-508.

Jautz, S. (2008). Gratitude in British and New Zealand radio programmes. Nothing but gushing? In K. P. Schneider \& A. Barron (eds.), Variational Pragmatics. A Focus on Regional Varieties in Pluricentric Languages (pp. 141-178). Amsterdam/Philadelphia: John Benjamins.

Jaworski A. (1995). "This is not an empty compliment!" - Polish compliments and the expression of solidarity. International journal of Applied Linguistics, 5(1), 63-94. http://dx.doi.org/10.1111/j.1473-4192.1995.tb00073.x

Kerbrat-Orecchioni, C. (1998). Les interactions verbales. Vol. 3. Paris: Armand Colin.

Kerbrat-Orecchioni, C. (2005). Les actes de langage dans le discours. Paris: Armand Colin.

Mulo Farenkia, B. (2009). Dire l'admiration à la camerounaise. Nordic Journal of African Studies, 18(1), 110-128. [Online] Available: http://www.njas.helsinki.fi/pdf-files/vol18num1/mulo_farenkia.pdf

Mulo Farenkia, B. (2012a). Compliment strategies and regional variation in French: Evidence from Cameroon and Canadian French. Pragmatics, 22(3), 447-476.

Mulo Farenkia, B. (2012b). Actes de langage et variation en français périphériques : étude comparée du compliment chez les jeunes au Québec et au Cameroun. Alternative francophone,
$1(5)$,
$1-25$.
[Online]
Available:

http://ejournals.library.ualberta.ca/index.php/af/article/view/12248/13626

Mulo Farenkia, B. (2012c). Expressing admiration in Quebec French and Cameroon French: A study in variational pragmatics. Philologie im Netz, 60, 48-66. [Online] Available: http://web.fu-berlin.de/phin/phin60/p60t3.htm

Schneider, K P., \& Barron, A. (eds.) (2008). Variational Pragmatics. A Focus on Regional Varieties in Pluricentric Languages. Amsterdam/Philadelphia: John Benjamins.

Schneider, K. P. (2005). No problem, you're welcome, anytime. Responding to thanks in Ireland, England, and the USA. In A. Barron, \& K. P. Schneider (eds.), The pragmatics of Irish English (pp. 101-139). Berlin / New York: Mouton de Gruyter. http://dx.doi.org/10.1515/9783110898934.101

Sifianou, M. (2001). "Oh! How appropriate" Compliments and politeness. In. A. Bayraktaroğlu \& M. Sifianou (eds.), Linguistic politeness across boundaries. The case of Greek and Turkish (pp. 391-430). Amsterdam / Philadelphia: John Benjamins.

Traverso, V. (1996). La conversation familière. Analyse pragmatique des interactions. Lyon: Presses Universitaires de Lyon. 


\section{Macrothink}

International Journal of Linguistics ISSN 1948-5425 2013, Vol. 5, No. 3

Ye, L. (1995). Complimenting in Mandarin Chinese. In. G. Kasper (ed.), Pragmatics of Chinse as native and target language (pp. 207-295). Honolulu, HI: University of Hawaii Press.

Yu, M-C. (2005). Sociolinguistic competence in the complimenting act of native Chinese and American English speakers: A mirror of cultural value. Language and speech, 48(1), 91-119. http://dx.doi.org/10.1177/00238309050480010501 